\title{
Middle Powers in International Development Cooperation: Assessing the Roles of South Korea and Turkey
}

\author{
R. Melis Baydag
}

\subsection{INTRODUCTION}

Fast-developing economies of the "Global South" have led to power shifts in international politics (Cornelissen 2009). It is believed that these rising, emerging, or latecomer countries play a pivotal role in future global governance (Cooper 2016; Okano-Heijmans 2012). They challenge "the Westerndominated patterns of international politics" (Schirm 2019, p. 2), as well as contribute to it (Grimm et al. 2009; Mawdsley 2012).

This chapter analyses the cases of South Korea (hereafter referred to as Korea) and Turkey as emerging powers in the field of development cooperation under the theoretical framework of Middle Power Theory (MPT). In international relations literature, they are considered as "emerging middle powers" (Bradford 2015; Cooper 2015b; Engin and Baba 2015; Jordaan 2003; Öniş and Kutlay 2017), which are members of the middle-power

R. Melis Baydag is currently a doctoral research associate and lecturer at the Chair of International Politics at Ruhr-University Bochum, Germany, melis.baydag@rub.de. This article benefits from the findings of Ms Baydag's master's thesis, titled The Role of Foreign Aid in Middle Power Diplomacy: Comparative Analysis of South Korea and Turkey (Baydag 2017) and defended on 16 June 2017.

R. M. Baydag $(\bowtie)$

Ruhr-University Bochum, Bochum, Germany

e-mail: melis.baydag@rub.de

(C) The Author(s) 2021

S. Chaturvedi et al. (eds.), The Palgrave Handbook of Development

Cooperation for Achieving the 2030 Agenda,

https://doi.org/10.1007/978-3-030-57938-8_20 
grouping MIKTA (Mexico, Indonesia, Korea, Turkey, Australia), established in 2013 at the margins of the United Nations (UN) General Assembly. MIKTA members claim to be like-minded peers as democracies and free market economies. Moreover, they show cooperative behaviour through multipolar, mediation oriented foreign policy activism (Manicom and Reeves 2014, p. 30).

Korea and Turkey make use of their middle-power identity with the aim of increasing their presence around the globe, where development cooperation is used as an important foreign policy tool (Baydag 2017). Both countries locate their foreign aid approaches between those of traditional donors, that is, the Development Assistance Committee (DAC) of the Organisation for Economic Co-operation and Development (OECD), which is mainly composed of advanced Western economies, ${ }^{1}$ and emerging donors, that is, developing countries of the Global South engaging with South-South Cooperation (SSC) based on a "horizontal cooperative relationship" (Klingebiel 2014, p. 19; Woods 2008). Nevertheless, whereas Korea positions itself more in line with the DAC, Turkey adopts a Southern narrative. ${ }^{3}$

The comparative study of Korea and Turkey reveals their divergent approaches to foreign aid discourse, ${ }^{4}$ which creates significant implications for global aid governance. Considering that effective international development cooperation based on a common framework depends on enhancing the dialogue between the DAC and the Southern providers (Fues et al. 2012, p. 144; Mawdsley 2012, p. 218), it is also crucial for Southern providers to reach common ground on their shared principles, which at the same time should lead towards efforts to fulfil the post-2015 agenda of the Sustainable Development Goals (Bracho 2018). As middle powers, Korea and Turkey have the capacity to contribute to the rapprochement between the traditional and the emerging donors as well as among the Southern providers. However, collaboration between the peers is seemingly being contested as a result of their divergent approaches to foreign aid, which stem from differing strategic and ideational paths in aid provision - the main focus of this chapter.

\subsection{Locating Korea AND Turkey in International Development CoOperation}

Broadly speaking, the increasing weight of emerging powers in international politics is primarily the result of the rise of the BRICS (Brazil, Russia, India, China, and South Africa), which wish to change the distribution of power in the system by actively participating in different policy fields of global governance (Ferguson 2015; Hurrell and Sengupta 2012). Before designating Korea and Turkey in international development as donors, first it is necessary to briefly mention the aspects of their emerging power characteristics.

Korea and Turkey are mid-sized, emerging countries in terms of economy, population, and resources (Çağaptay 2013; Chin and Quadir 2013; Schirm 2019). In this respect, clustered among the second tiers, they are not expected 
to reach the BRICS level in terms of global ranking and are instead expected to remain regional players (Cooper 2015b). Nevertheless, Korea and Turkey combine their growing economic power with political power (Chin and Quadir 2013; Manning 2006; Woods 2008), that is, political power in the sense of active participation in global decision-making processes (Florini 2011; Klingebiel 2016, 2017). Additionally, they are not challengers of the liberal developed West ${ }^{5}$ and remain integrated into the system of Western alliances (Hurrell 2006). Last but not least, they are expected to play an essential role in sharing the burden of global challenges such as financial crises, climate change, and development (Flemes and Habib 2009; Grimm et al. 2009).

The mainstream development cooperation agenda is largely dominated by Western practices and includes bilateral agencies, multilateral organisations, and even non-governmental organisations (Mawdsley 2012, p. 2). The term "mainstream" therefore refers to the foreign aid behaviours of the traditional donors, summarised as follows (Fues et al. 2012): traditional donors tend to emphasise altruistic motives in aid-giving by "concealing" their self-interest, unlike Southern providers, who frame their aid mostly in terms of mutual benefit based on solidarity and economic progress, resulting in a "win-win" situation (Fues et al. 2012, p. 139). In addition, traditional donors set political conditionality in their aid provision, especially regarding governance criteria such as the protection of human rights or the rule of law, which, in the past, has led to external interference in the political affairs of low-income countries. Although this started changing when many Western providers became more careful about not imposing culturally biased values, they still do not insist on the primacy of national sovereignty in all aspects of international relations as much as the Southern providers do. In this respect, the principle of noninterference, together with a pragmatic interest-based approach, is more visible in Southern foreign aid behaviour (Fues et al. 2012, p. 140).

On the one hand, Korea's and Turkey's aid discourses converge with those of traditional donors as a result of them being OECD members (i.e. Korea being a DAC member and Turkey regularly reporting to the Committee). In other words, they have traditionally been part of the mainstream aid agenda and do not significantly diverge from the Committee (Cihangir-Tetik and Müftüler-Baç 2018; Hausmann 2014; Stallings and Kim 2017).

On the other hand, their official discourses put emphasis on providing better approaches to development cooperation with insights from SSC. This has gained prominence among Southern providers as an alternative to traditional donor-recipient relations, which are based on "one-way giving", in order to eliminate the differentiation between partners (Davis and Taylor 2015 , p. 154; Mawdsley 2012). The stress on eliminating differentiation in particular explains well how the official foreign aid discourses of both Korea and Turkey converge with those of the emerging donors of the South.

To illustrate, Korea focusses on "learning from experience" in its official motto and positions it as a model that is based on its own experience of receiving and using aid for poverty eradication-and most importantly in 
becoming a DAC donor as a result of its development success (Stallings and Kim 2017). Turkey, on the other hand, after a brief period of rapprochement with the OECD-DAC, has adopted a foreign aid discourse detached from the Committee, which envisages a global role for Turkey through its engagement with Southern partners, wherein Turkey will ideationally rebuild the historical and cultural ties of the Ottoman Empire (Donelli and Levaggi 2016).

Despite convergences with both camps, the foreign aid aspirations of Korea and Turkey can be further elaborated by referring to their mindset for following certain strategies in international development cooperation. In this respect, neither donor can be simply categorised as an emerging or traditional donor. The next section emphasises ideational aspects of their proactive role in employing the presumptions of the MPT as a significant cornerstone in positioning both countries within the international development cooperation system.

\subsection{Middle-Power Theories}

Middle powers are not as influential or powerful as great powers, but they still have a considerable amount of influence in promoting cohesion and stability in the international system (Chapnick 1999; Glazebrook 1947; Jordaan 2003). In other words, they are not powerful enough to act alone, but they are effective in collective action with either like-minded peers that have similar capacities or less powerful ones (Da Silva et al. 2016). They are also effective when acting through international organisations (Flemes and Habib 2009).

At first, the term "middle" evokes a positional understanding based on a hierarchy of states and material capabilities, for example size, population, or resources. Some scholars also emphasise their functional importance, whereby they either follow a great power or resort to niche diplomacy in international affairs (Chapnick 1999). Both approaches, however, do not reflect the assumptions of MPT in ideational terms. Of the different definitions, therefore, this chapter relies on the behavioural approach to MPT, with the following elements serving as the underlying determinants.

First, middle powers take positions in international disputes as mediators and pursue diplomacy by relying on the notion of "good international citizenship" (Cooper et al. 1993). Second, the state's will to-and capacity for-dedicating itself to becoming a middle power in accordance with good international citizenship is significant (Bélanger and Mace 1997; Hynek 2004). Third, middle powers are considered to be driven by "a role conception resting on the notion of a distinctive mode of statecraft" (Hynek 2004, p. 36).

Constructivist theory has strong foundations in behavioural approaches. It is assumed that the identity of a state-constructed by the country itselfdetermines its position in international politics. In that vein, non-material structures define actors' identities and form their interests (Finnemore and Sikkink 2001) in "how they think they should act, what perceived limitations 
on their actions are and what strategies they can imagine" (Reus-Smit 2005, p. 197). To that effect, middle-power identity is strategically constructed to justify actions and interests. Accordingly, Cooper (2015a) argues that using a flexible form of behaviour and strengthening the international system through diplomatic means are distinguishing characteristics of middle powers (Cooper 2015a, p. 35). They pursue multilateral solutions to global issues by affecting international outcomes (Cooper et al. 1993, p. 19; O'Neil 2015, p. 75) and being political representatives of "the social, environmental and human interests of humanity" (Bradford 2015, p. 9).

\subsection{Like-Minded Peers or Counterparts?}

Based on the theoretical framework of this chapter, the increasing influence of Korea and Turkey can be linked to their adopted middle-power identities. Hence, they are not simply second-tier emerging donors of growing political and economic importance. Their rise, in John's (2014) words, can also be considered as "a new discourse of [international relations] from the middlepower perspective as an alternative to the dominant narrative of great powers" (John 2014, p. 332).

Korea and Turkey claim to provide a better perspective based on their long history as aid recipients. Korea and Turkey also differ from some of the significant emerging donors, such as China and Russia, since they do not radically challenge the established system and have long been bound by Western institutions and practices (Hausmann 2014; Hausmann and Lundsgaarde 2015; Kim et al. 2013). Notwithstanding the above, their declarations of being like-minded peers in international cooperation do not seem to have led to converging perspectives on foreign aid.

Starting from this point, the chapter proceeds as follows. First, the official middle-power discourses of Korea and Turkey are introduced, and the role of foreign aid as a foreign policy tool is highlighted. Second, the foreign aid discourses of Korea and Turkey are discussed. Third, the section concludes with comparative results in relation to the OECD-DAC. In this respect, the OECD-DAC constitutes the main reference point for categorising the two donors for the purpose of comparing their discourses-not only to each other, but also to their traditional counterparts.

\subsubsection{Global Visibility Through Middle-Power Strategies}

Korea and Turkey take part in multilateral platforms that promote international commitments. Korea hosted the Fourth High Level Forum on Aid Effectiveness in 2011 in Busan. Following that, it has been actively engaging with the annual Busan Global Partnership for Effective Development Co-operation (GPEDC) since 2014 for encouraging and monitoring the country-level implementation of the Busan principles. Despite being a 
participant, Turkey has not been an active stakeholder in the GPEDC. In fact, Turkey's interests lay in humanitarianism from a least-developed country (LDC) perspective. Turkey hosted the Fourth UN Conference on the Least Developed Countries in 2011, promoting people-centred sustainable development (United Nations 2011). Turkey was also the first to host a UN humanitarian summit in 2016, urging for the delivery of foreign aid to end need (World Humanitarian Summit 2016).

More specifically, Korea launched the New Asian Initiative in 2009 under the Lee Myung-bak government, which attributed a leadership role to Korea as the leading voice of Asian countries in international platforms (O'Neil 2015, p. 84). Korea's membership in the OECD-DAC in 2010 has further reinforced its global position as the first country that went from being an LDC to a DAC donor (O'Neil 2015, p. 85). It was followed by the launch of the Global Korea initiative in 2012, in which official development assistance (ODA) is used as one of the policy instruments (Ko 2012, p. 296). Then-Vice Minister of Foreign Affairs and Trade, Sung-han Kim (2013), emphasised Korea's role as a middle power by stating that "[Middle powers] can lead a meaningful change in the world. They do so not by power, but through creative ideas, a smart and flexible strategy, and moral leadership" (Kim 2013).

In the case of Turkey, the current foreign minister, Mevlüt Çavuşoğlu, characterises Turkish foreign policy as "enterprising and humanitarian" (Republic of Turkey Ministry of Foreign Affairs [MFA Turkey] n.d.-a). The readings of former Prime Minister Ahmet Davutoğlu (2012) describe Turkey as a "central country with multiple regional identities" and presume that Turkey's identity will be transformed into a global power the more that it actively engages with global politics (Davutoğlu 2012, p. 83). Nevertheless, such an argument would be an unrealistic interpretation of Turkey's power because "there is no room in the existing international order for a medium-sized regional power to upgrade itself into a regional sub-superpower status" (Türkeş 2016, p. 211).

Although Turkey does not seem to be adopting a middle-power identity, the official discourse of the Turkish government comports with the theory's main assumptions. In fact, a middle power does not always have to behave in the way that the theory suggests (Gilley and O'Neil 2014). This chapter assumes Turkey to be a middle power because of its membership in MIKTA and as a result of the recent increase in its assertive of foreign policy matters (Cooper 2015b; Öniş 2011; Öniş and Kutlay 2017; Parlar Dal 2014). In official discourse, Turkey is identified as a humanitarian power that does not remain "indifferent to the developments in the world, assumes a reconciliatory, constructive and intermediary role in order to reach amicable solutions for the global problems" (Turkish Cooperation and Coordination Agency 2014 , p. 2). Its middle-power role is based on an active regional and global involvement (Baba 2018; Meral and Paris 2010). 


\subsubsection{Foreign Aid Narratives}

Generally speaking, Korea and Turkey emphasise their shared experiences with the developing world, thus differentiating their approaches to foreign aid from Western aid providers (Bilgic and Nascimento 2014, p. 2; Chun et al. 2010, p. 798). As mentioned in the joint statement of the Fourth MIKTA Foreign Ministers' Meeting, "MIKTA, as a consultative forum and innovative partnership, could play a bridging role between advanced countries and developing countries on key global issues" (MFA Turkey 2014).

Individual cases show that Korea's successful development story as a recipient is the primary aspect that the government highlights. Accordingly, Korea claims to base its foreign aid policy on "learning from experience" (Howe 2015; Stallings and Kim 2017). Korea's own history of economic development is the main source of its strength (Bradford 2015, p. 10), and Korea sees its OECD-DAC membership as a benchmark for measuring its level of achievement, since it gives Korea the chance to be recognised as a developed country (Chun et al. 2010).

In contrast to Korea, Turkey defines its development cooperation along the lines of the idealistic and cultural terms established through history and based on a humanitarian-sensitive generosity in aid-giving, particularly in neighbouring regions (Kardaş 2013; Kulaklıkaya and Nurdun 2010). The famine in Somalia in 2011 was the turning point for Turkey's rise as a humanitarian power that combined pure humanitarianism with "business ties, peace-building initiatives, education, infrastructure and development aid, and even military aid" and served as a model for its engagements with Africa (Gilley 2015 , p. 39). The emphasis on solidarity and brotherhood in Somalia also signified its turn to the Global South (Donelli and Levaggi 2018; Stearns and Sucuoglu 2017).

The main divergence in the foreign aid discourses of the donors stems from how they position themselves as aid providers. Korea's attempt to distinguish itself as a DAC donor is basically done to gain more global reach and prestige. Korea realises its middle-power diplomacy by relying on its own development experience, and by emphasising the global characteristic of its development approach. Turkey focuses on cultural (as well as linguistic and religious) aspects, combined with a humanitarian stance. Turkey uses its geographical advantage and does not necessarily speak about a specific global development model. In this sense, its foreign aid discourse tends to be more region- and/or culture-specific.

\subsubsection{Korea and Turkey in Relation to the OECD-DAC}

The cases of Korea and Turkey offer both insider and outsider perspectives with regard to relations with the OECD-DAC. Korea and Turkey are insiders due to them being a DAC member and a DAC observer, respectively. When we look at it from the angle that both countries are emerging donors, how 
they seek to bring new perspectives to the provisioning of foreign aid becomes a relevant reference point. It is therefore significant to point out where Korea and Turkey - as both OECD members and Southern providers—stand in this picture.

\subsubsection{Korea}

The Korean foreign ministry highlights that Korea is a "recipient-turneddonor" country (Republic of Korea Ministry of Foreign Affairs n.d.). The Korean government stresses Korea's distinctive development achievement that started after the Korean War in the 1950s, when the only source of economic growth was based on foreign aid (Kim 2011). Korea's past experience as a recipient and its donor status achievement within the DAC are significant aspects. As Mawdsley suggested, "for South Korea, membership of the DAC represents another marker of international status" (Mawdsley 2012, p. 177). For some scholars, Koreans are proud of their achievement and ambitious to align their development programmes with the experiences of their own development (Chun et al. 2010). It is used as a way to distinguish Korea from traditional Western donors.

Korean aid can also be considered as being in a transition period. According to a scholar working on Korean development aid, some aspects of Korea's development cooperation reflect SSC "in spirit or in practice", while at the same time Korea is working with the DAC and "speaks the same language with it" (personal communication, 12 October 2016). In other words, although some aspects of Korea's donor behaviour still reflect an Asian model that was formerly represented by Japan (e.g. mixing aid and trade), Korea remains within the boundaries of the accepted norms and guidelines of the DAC (e.g. untying aid or increasing multilateral aid) (Stallings and Kim 2017, p. 97). Most importantly, governmental discourse does not refrain from associating Korean aid with Western aid.

\subsubsection{Turkey}

Turkey shares a long history of alliances and partnerships with the Western powers, which led its foreign aid policy to converge with Western practices (Donelli and Levaggi 2018; Mawdsley 2012). Turkey does not radically challenge the DAC principles. For instance, it is a participant of OECD-led platforms such as the GPEDC. However, the foreign policy shift since the early 2000s has led to an increasing Southern dimension in its foreign aid policy. Nowadays, Turkey officially considers itself to be one of the new aid providers actively engaging in SSC (MFA Turkey n.d.-b). As an official in the Turkish Cooperation and Coordination Agency assessed, joining the DAC does not seem to be one of its priorities in the near future (personal communication, 18 January 2017). 
Table 20.1 Comparing Korea (KR) and Turkey (TR)

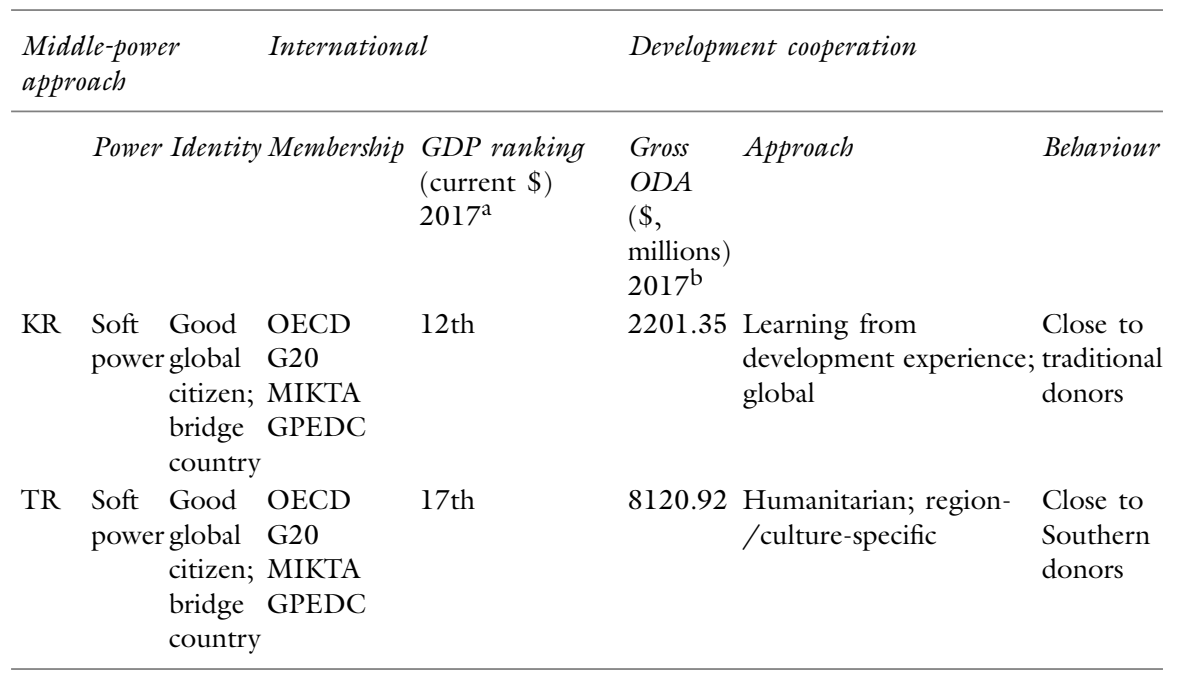

Sources ${ }^{\mathrm{a}}$ World Bank (2017); ${ }^{\mathrm{b}}$ See other years on OECD.Stat (Organisation for Economic Co-operation and Development 2017)

The interplay between external factors (e.g. rise of non-Western powers, 2008 financial crisis, and the aftermaths of the Arab uprising) and internal factors (the ideological orientation of the ruling party based on Islamic conservatism) has strengthened Turkey's Southern narratives (Donelli and Levaggi 2018 , p. 95). In addition, the ruling party's status-seeking foreign policy strategy of "presenting itself as a regional order-builder to the surrounding regions" has further contributed to it (Donelli and Levaggi 2018, p. 58). Such a discourse seems to have alienated Turkey from a Western approach in development cooperation (Table 20.1).

\subsection{POLICY IMPLICATIONS}

This chapter elaborates on the foreign aid behaviours of Korea and Turkey as emerging middle powers, broadly in international relations and specifically in development cooperation. Korea and Turkey are contributors to the new context in which development cooperation is taking place. They play active middle-power roles and are asserting their power to assume a moral stance as well as global responsibility. Despite claiming to be like-minded peers, they leave the issue of collaboration in international development cooperation contested by adopting an official discourse based on divergent narratives on development aid. In this regard, their role as significant aid providers should be studied carefully for further attempts at collaboration at the global level.

Today, a comprehensive partnership in international development is needed to address the visibly urgent global challenges. In the same vein, international 
development is in a transition period, whereby traditional donors are trying to maintain the status quo, and the emerging ones are challenging the established system. Middle powers play a role by either stabilising the system or decreasing the friction between clashing donor strategies. In this picture, Korea and Turkey could possibly be important binding stakeholders that contribute to the convergence between practices and values of different aid providers in the field. For that reason, their claim of being a bridge between the developed and the developing worlds should not be neglected by policy-makers and practitioners, despite the growing divergence in their approaches.

By the same token, we also see that the differing discursive stances of similar donors, such as Korea and Turkey, create a messier picture rather than positively contributing to the transformation of development cooperation as a policy area. In other words, global partners find it difficult to reach a global consensus in the presence of divergent approaches. Consequently, this contribution is significant in unveiling the core differences between seemingly similar aid providers, and therefore, it should be taken as a reminder of the challenges to global efforts to achieve international collaboration. Divergent foreign aid motivations of similar donors mentioned in this chapter might help us to formulate new ways of handling global aid governance, otherwise pledges for furthering cooperation remain mere lip service.

\subsection{Further REsearch}

Further studies on Korea and Turkey should focus on whether their development cooperation practices (actual aid flows) are compatible with their foreign aid discourses, because discourse does not always accurately reflect reality. More generally, a domestic politics perspective should not be neglected in studying foreign aid policy, as its political economy requires examining the domestic economic context in which aid decisions are made (Lundsgaarde 2013). It would be worth paying attention to the extent to which issue-specific controversies on the global level result from the heterogeneity of governmental preferences at the domestic level (Schirm 2013). This would also contribute to the discussions on the divergent/convergent approaches among different donors in global aid governance. Last but not least, the middle-power concept should be further clarified, since a wide range of states are now considered to be middle powers but are too diverse to identify a common pattern of middle-power behaviour (Jordaan 2017).

\section{Notes}

1. Among traditional DACdonors, Japan is the only Asian country. Korea became a DAC donor in 2010 and is therefore not yet considered a traditional donor.

2. The United Nations Office for South-South Cooperation defines SSC as "sharing knowledge, skills, expertise and resources to meet development goals 
through concerted efforts" (United Nations Office for South-South Cooperation n.d.).

3. The term "narrative" is understood as "a representation of a particular situation or process in such a way as to reflect or conform to an overarching set of aims or values". The definition was retrieved from https://en.oxforddictionaries.com/ definition/narrative.

4. The term "discourse" is understood as "written or spoken communication or debate". The definition was retrieved from https://en.oxforddictionaries.com/ definition/discourse.

5. The majority of the BRICS countries are historically challengers of the liberal developed West, exemplified, among other things, by the Revolutionism of the Soviet Union and China, the hard-revisionist Third Worldism in post-1948 India, and the soft-revisionist Third Worldism of Brazil in the early 1970s and late 1980s (Hurrell 2006, p. 3). Most of the second tiers, on the contrary, have been part of an alliance led by a greater power. For instance, countries allied with the United States, such as Korea and Turkey (Wright 2015), have long benefited from its bilateral security and economic relations (Ikenberry 2004).

\section{REFERENCES}

Baba, G. (2018). Turkey's multistakeholder diplomacy: From a middle power angle. In E. Parlar Dal (Ed.), Middle powers in global governance: The rise of Turkey (pp. 5981). Cham: Palgrave Macmillan.

Baydag, R. M. (2017). The role of foreign aid in middle power diplomacy: Comparative analysis of South Korea and Turkey. Master's thesis, Middle East Technical University, Ankara, Turkey.

Bélanger, L., \& Mace, G. (1997). Middle powers and regionalism in the Americas: The cases of Argentina and Mexico. In A. F. Cooper (Ed.), Niche diplomacy: Middle powers after the Cold War (pp. 164-183). New York, NY: St. Martin's Press.

Bilgic, A., \& Nascimento, D. (2014, September). Turkey's new focus on Africa: Causes and challenges (Policy Brief). Oslo: Norwegian Peacebuilding Resource Centre.

Bracho, G. (2018). Towards a common definition of South-South cooperation: Bringing together the spirit of Bandung and the spirit of Buenos Aires. Development Cooperation Review, 1(6), 9-13.

Bradford, C. I. (2015). South Korea as a middle power in global governance: "Punching above its weight" based on national assets and dynamic trajectory. In S. A. Snyder (Ed.), Middle-power Korea (pp. 8-20). New York, NY: Council on Foreign Relations Press.

Çăgaptay, S. (2013). Defining Turkish power: Turkey as a rising power embedded in the Western international system. Turkish Studies, 14(4), 797-811.

Chapnick, A. (1999). The middle power. Canadian Foreign Policy Journal, 7(2), 73-82.

Chin, G., \& Quadir, F. (2013). Introduction: Rising states, rising donors and the global aid regime. Cambridge Review of International Affairs, 25(4), 493-506.

Chun, H.-M., Munyi, E. N., \& Lee, H. (2010). South Korea as an emerging donor: Challenges and changes on its entering OECD/DAC. Journal of International Development, 22(6), 788-802. 
Cihangir-Tetik, D., \& Müftüler-Baç, M. (2018). Turkey's compliance with the European Union's development policy: A pattern of external differentiated integration? Journal of European Integration, 40(7), 939-959.

Cooper, A. F. (2015a). G20 middle powers and initiatives on development. In J. Mo (Ed.), MIKTA, middle powers, and new dynamics of global governance (pp. 32-46). New York, NY: Palgrave Macmillan.

Cooper, A. F. (2015b). MIKTA and the global projection of middle powers: Toward a summit of their own? Global Summitry, 1(1), 95-114.

Cooper, A. F. (2016). Testing middle power's collective action in a world of diffuse power. International Journal, 71(4), 529-544.

Cooper, A. F., Higgott, R. A., \& Nossal, K. R. (1993). Relocating middle powers: Australia and Canada in a changing world order. Vancouver: UBC Press.

Cornelissen, S. (2009). Awkward embraces: Emerging and established powers and the shifting fortunes of Africa's international relations in the twenty-first century. Politikon, 36(1), 5-26.

Da Silva, A. L. R., Spohr, A. P., \& da Silveira, I. L. (2016). From Bandung to Brasilia: IBSA and the political lineage of South-South cooperation. South African Journal of International Affairs, 23(2), 167-184.

Davis, R., \& Taylor, I. (2015). "Africa rising" and the rising powers. In J. Gaskarth (Ed.), Rising powers, global governance and global ethics (pp. 152-172). New York, NY: Routledge.

Davutoğlu, A. (2012). Stratejik derinlik: Türkiye'nin uluslararası konumu. İstanbul: Küre Yayınları.

Donelli, F., \& Levaggi, A. G. (2016). Becoming global actor: The Turkish agenda for the Global South. Rising Powers Quarterly, 1(2), 93-115.

Donelli, F., \& Levaggi, A. G. (2018). From Mogadishu to Buenos Aires: The Global South in the Turkish foreign policy in the late JDP period (2011-2017). In E. Parlar Dal (Ed.), Middle powers in global governance: The rise of Turkey (pp. 53-76). Cham: Palgrave Macmillan.

Engin, B., \& Baba, G. (2015). MIKTA: A functional product of new middle powerism. Uluslararası Hukuk ve Politika, 11(42), 1-40.

Ferguson, Y. H. (2015). Rising powers and global governance. In J. Gaskarth (Ed.), Rising powers, global governance and global ethics (pp. 21-40). New York, NY: Routledge.

Finnemore, M., \& Sikkink, K. (2001). The constructivist research program in international relations and comparative politics. Annual Review Political Science, 4, 391-416.

Flemes, D., \& Habib, A. (2009). Introduction: Regional powers in contest and engagement: Making sense of international relations in a globalised world. South African Journal of International Affairs, 16(2), 137-142.

Florini, A. (2011). Rising Asian powers and changing global governance. International Studies Review, 13(1), 24-33.

Fues, T., Chaturvedi, S., \& Sidiropoulos, E. (2012). Towards a global consensus on development. In S. Chaturvedi, T. Fues, \& E. Sidiropoulos (Eds.), Development cooperation and emerging powers: New partners or old patterns? (pp. 138-148). London: Zed Books.

Gilley, B. (2015). Turkey, middle power, and the new humanitarianism. Perceptions, 20(1), 37-58. 
Gilley, B., \& O'Neil, A. (2014). China's rise through the prism of middle powers. In B. Gilley \& A. O'Neil (Eds.), Middle powers and the rise of China (pp. 1-22). Washington, DC: Georgetown University Press.

Glazebrook, G. D. (1947). The middle powers in the United Nations. International Organisation, 1(2), 307-315.

Grimm, S., Humphrey, J., Lundsgaarde, E., \& De Sousa, S.-L. J. (2009). European development cooperation to 2020: Challenges by new actors in international development (Working Paper No. 4). Bonn: European Association of Development Research and Training Institutes.

Hausmann, J. (2014). Turkey as a donor country and potential partner in triangular cooperation (Discussion Paper No. 14). Bonn: German Development Institute/Deutsches Institut für Entwicklungspolitik (DIE).

Hausmann, J., \& Lundsgaarde, E. (2015). Turkey's role in development cooperation (Working Paper). Bonn: United Nations University Centre for Policy Research.

Howe, B. (2015). Development effectiveness: Charting South Korea's role and contribution. In S. A. Snyder (Ed.), Middle-power Korea (pp. 21-43). New York, NY: Council on Foreign Relations Press.

Hurrell, A. (2006). Hegemony, liberalism and global order: What space for would-be great powers? International Affairs, 82(1), 1-19.

Hurrell, A., \& Sengupta, S. (2012). Emerging powers, North-South relations and global climate politics. International Affairs, 88(3), 463-484.

Hynek, N. (2004). Canada as middle power: Conceptual limits and promises. The Central European Journal of Canadian Studies, 4(1), 33-43.

Ikenberry, G. J. (2004). Liberalism and empire: Logics of order in the American unipolar age. Review of International Studies, 30(4), 609-630.

John, J. V. (2014). Becoming and being a middle power: Exploring a new dimension of South Korea's foreign policy. China Report, 50(4), 325-341.

Jordaan, E. (2003). The concept of a middle power in international relations: Distinguishing between emerging and traditional middle powers. Politikon, 30(1), $165-181$.

Jordaan, E. (2017). The emerging middle power concept: Time to say goodbye? South African Journal of International Affairs, 24(3), 395-412.

Kardaş, Ş. (2013). Turkey: A regional power facing a changing international system. Turkish Studies, 14(4), 637-660.

Kim, J. (2011). Foreign aid and economic development: The success story of South Korea. Pacific Focus, 26(2), 260-286.

Kim, S. (2013). Global governance and middle powers: South Korea's role in the G20. http://www.cfr.org/south-korea/global-governance-middle-powerssouth-koreas-role-g20/p30062.

Kim, E. M., Kim, P. H., \& Kim, J. (2013). From development to development cooperation: Foreign aid, country ownership, and the developmental state in South Korea. The Pacific Review, 26(3), 313-336.

Klingebiel, S. (2014). Development cooperation: Challenges of the new aid architecture. Basingstoke: Palgrave Macmillan, UK.

Klingebiel, S. (2016). Global problem-solving approaches: The crucial role of China and the group of rising powers. Rising Powers Quarterly, 1(1), 33-41. 
Klingebiel, S. (2017). Rising powers and the provision of transitional public goods: Conceptual considerations and features of South Africa as a case study (Discussion Paper No. 3). Bonn: German Development Institute/Deutsches Institut für Entwicklungspolitik (DIE).

Ko, S. (2012). Korea's middle power activism and peacekeeping operations. Asia Europe Journal, 10, 287-299. https://doi.org/10.1007/s10308-012-033.

Kulaklıkaya, M., \& Nurdun, R. (2010). Turkey as a new player in development cooperation. Insight Turkey, 12(4), 131-145.

Lundsgaarde, E. (2013). The domestic politics of foreign aid. New York, NY: Routledge.

Manicom, J., \& Reeves, J. (2014). Locating middle powers in international relations theory and power transitions. In B. Gilley \& A. O’Neil (Eds.), Middle powers and the rise of China (pp. 23-44). Washington, DC: Georgetown University Press.

Manning, R. (2006). Will "emerging donors" change the face of international cooperation? Development Policy Review, 24(4), 371-385.

Mawdsley, E. (2012). From recipients to donors: Emerging powers and the changing development landscape. London: Zed Books.

Meral, Z., \& Paris, J. (2010). Decoding Turkish foreign policy hyperactivity. The Washington Quarterly, 33(4), 75-86.

MFA Turkey (Republic of Turkey Ministry of Foreign Affairs). (n.d.-a). Turkey's enterprising and humanitarian foreign policy. http://www.mfa.gov.tr/synopsis-of-the-tur kish-foreign-policy.en.mfa.

MFA Turkey. (n.d.-b). Turkey's development cooperation: General characteristics and the least developed countries (LDC) aspect. http://www.mfa.gov.tr/turkey_s-develo pment-cooperation.en.mfa.

MFA Turkey. (2014). Joint statement of the 4th MIKTA foreign ministers' meeting, 15 November 2014. http://www.mfa.gov.tr/joint-statement-of-the-4th-mikta-foreignministers_-meeting_-15-november-2014.en.mfa.

Okano-Heijmans, M. (2012). Power shift: Economic realism and economic diplomacy on the rise. In E. Fels, J.-F. Kremer, \& K. Kronenberg (Eds.), Power in the 21st century: International security and international political economy in a changing world (pp. 269-286). Berlin and Heidelberg: Springer.

O'Neil, A. (2015). South Korea as a middle power: Global ambitions and looming challenges. In S. A. Snyder (Ed.), Middle-power Korea (pp. 75-89). New York, NY: Council on Foreign Relations Press.

Öniş, Z. (2011). Multiple faces of the "new" Turkish foreign policy: Underlying dynamics and a critique. Insight Turkey, 13(1), 47-65.

Öniş, Z., \& Kutlay, M. (2017). The dynamics of emerging middle-power influence in regional and global governance: The paradoxical case of Turkey. Australian Journal of International Affairs, 71(2), 164-183.

Organisation for Economic Co-operation and Development. (2017). Total flows by donors (ODA+OOF+Private) [DACl]. https://stats.oecd.org/.

Parlar Dal, E. (2014). On Turkey's trail as a "rising middle power" in the network of global governance: Preferences, capabilities, and strategies. Perceptions, 19(4), 107-136.

Republic of Korea Ministry of Foreign Affairs. (n.d.). Korea's development: History of its transformation. http://www.mofa.go.kr/ENG/policy/oda/Overview/index. jsp?menu=m_20_110_30. 
Reus-Smit, C. (2005). Constructivism. In S. Burchill \& A. Linklater (Eds.), Theories of international relations (3rd ed., pp. 189-212). New York, NY: Palgrave Macmillan.

Schirm, S. A. (2013). Global politics are domestic politics: A societal approach to divergence in the G20. Review of International Studies, 39(3), 685-706.

Schirm, S. A. (2019). In pursuit of self-determination and redistribution: Emerging powers and Western anti-establishment voters in international politics. Global Affairs, 5(2), 115-130.

Stallings, B., \& Kim, E. M. (2017). Promoting development: The political economy of East Asian foreign aid. London: Palgrave Macmillan.

Stearns, J., \& Sucuoglu, G. (2017). South-South cooperation and peacebuilding: Turkey's involvement in Somalia (Policy Insights No. 43). Johannesburg: The South African Institute of International Affairs.

Turkish Cooperation and Coordination Agency. (2014). Turkish development assistance: From Turkey to the world. http://www.tika.gov.tr/upload/2016/INGILI ZCESITEESERLER/KALKINMARAPORLARI/DAReport2014.pdf.

Türkeş, M. (2016). Decomposing neo-Ottoman hegemony. Journal of Balkan and Near Eastern Studies, 18(3), 191-216.

United Nations. (2011). Istanbul declaration. http://www.un.org/wcm/webdav/ site/ldc/shared/documents/SummaryofoutcomedocumentsofPCEs.pdf.

United Nations Office for South-South Cooperation. (n.d.). What is South-South cooperation? http://ssc.undp.org/content/ssc/about/what_is_ssc.html.

Woods, N. (2008). Whose aid? Whose influence? China, emerging donors and the silent revolution in development assistance. International Affairs, 84(6), 12051221.

World Bank. (2017). World development indicators. https://data.worldbank.org/ind icator/NY.GDP.MKTP.CD.

World Humanitarian Summit. (2016). Changing people's lives: From delivering aid to ending need. https://consultations.worldhumanitariansummit.org/bitcache/le8 a030537b584bb62c7d75f71062383e24ff542 ?vid=575820\&disposition=inline \&op= view.

Wright, T. (2015). Middle powers and the middle pivot. In J. Mo (Ed.), MIKTA, middle powers, and new dynamics of global governance (pp. 13-31). New York, NY: Palgrave Macmillan.

Open Access This chapter is licensed under the terms of the Creative Commons Attribution 4.0 International License (http://creativecommons.org/licenses/by/4.0/), which permits use, sharing, adaptation, distribution and reproduction in any medium or format, as long as you give appropriate credit to the original author(s) and the source, provide a link to the Creative Commons license and indicate if changes were made.

The images or other third party material in this chapter are included in the chapter's Creative Commons license, unless indicated otherwise in a credit line to the material. If material is not included in the chapter's Creative Commons license and your intended use is not permitted by statutory regulation or exceeds the permitted use, you will need to obtain permission directly from the copyright holder.

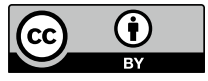

